\title{
Age and Education Distribution Patterns of Working Mothers on Dental Health Behavior in Preschool Children in Mid-Class Society
}

\author{
Isnawati $^{1}$, Darmawan Setijanto ${ }^{2}$, Taufan Bramantoro ${ }^{2}$, Dinda Dewi Zalinda ${ }^{3}$ \\ ${ }^{l}$ Master Program of Dental Health Science, ${ }^{2}$ Department of Dental Public Health, Faculty of Dental \\ Medicine, Universitas Airlangga; ${ }^{3}$ Department of Health, Vocational Faculty, Universitas Airlangga
}

\begin{abstract}
Background: Dental caries is a common disease in children which if left untreated, it may affect weight, growth and the quality of life in childhood. The behavior of parents, especially mothers, affects the children's oral health, because mothers aside of being the decision maker for the children, they also have careers.

Objective: This study aimed to analyze the relationship between age and education of working mothers on dental health behaviors in pre-schooled children aged 5-6 years.

Method: This was a cross-sectional study, involving working mothers who have children aged 5-6 years in Banjarbaru, South Kalimantan. The number of respondents was 101 working caregivers, that was chosen by means of a cluster random sampling technique. The data were obtained through interview and questionnaire. The results were analyzed statistically using logistic regression test with a significance value of $p<0.05$.

Results: There was no significant relationship between age and education of working mothers on dental health behaviors in preschoolers.

Conclusion: The age and education of working mothers are not related to dental health behavior in preschool children in Banjarbaru South Kalimantan.
\end{abstract}

Keywords: age, education, mother behavior

\section{Introduction}

The World Health Organization (WHO) stated that $60-90 \%$ of school children worldwide suffered from caries $^{1}$, a common disease which if untreated, it may affect weight, growth, and quality of life, especially in childhood ${ }^{2}$. Basic Health Research in 2013 stated that dental and oral health in Indonesia remained quiet apprehensive. The high prevalence of dental and

\section{Corresponding Author:}

Taufan Bramantoro

Department of Dental Public Health,

Faculty of Dental Medicine, Universitas Airlangga,

Jl. Mayjend Prof Dr Moestopo 47, 60132

Surabaya, Indonesia

Phone: +62 315030255

Email: taufan-b@fkg.unair.ac.id oral health problems was found in South Kalimantan Province $(36.1 \%)$, making it the second highest after South Sulawesi $(36.2 \%)^{3}$. Previous research, analyzing the relationship of dental caries with the quality of life in school children aged 5-7 years in Landasan Ulin Sub-district, Banjarbaru, South Kalimantan proved the average of primary tooth suffering dental caries as many as 9 teeth per children ${ }^{4}$. Parents have main role in providing the information and encouraging a healthy living. The knowledge, beliefs, and attitudes of parents affect oral health, eating habits and the health behaviors of children ${ }^{5}$. Parental behavior, especially mothers, affects the oral health of children because mother acts as a primary caregiver and the ultimate decision maker ${ }^{6,7}$ socioeconomic status, oral health behaviors of children and their parents. Oral health status of children was examined. The parent and their children oral health relationship were tested using regression and correlation analysis. Results. About 222 parents and 
children participated in the study. There was a significant relationship between history of having dental problems in parents and dmft index in their children $(\mathrm{P}=0.01$.

The Central Bureau of Statistics in Banjarbaru, South Kalimantan, stated that in 2015, 62.45\% of women worked as a bureaucrat. Women working in the public sphere for economic and social motivation; to increase family income and not depend on husband ${ }^{8}$, while the social motivation are education level, free time, seeking for experience and self-actualization'. The socio-economic status of the family greatly affects the family's need compliance to achieve a prosperous standard of living and maximum health ${ }^{10}$.

Working women in Banjarbaru are classified to middle-class society for having a fixed income and well educated. Middle-class society is a social class with occupation and fixed income, modern society which is economically prosperous, and well-educated and considered as an important person by the surrounding society ${ }^{11}$. Health behavior is formed by three main factors; predisposing factors, namely knowledge, attitude, belief, values, age, education, occupation, and family economic status. The second are supporting factors are the physical environment, health facilities and infrastructure and health program. The last is supporting factor of the attitudes and actions of health workers or others who become role models ${ }^{12}$.

The purpose of this study was to analyze the relationship between age and education of working mothers on the dental health behavior of preschool children aged 5-6 years in Banjarbaru, South Kalimantan.

\section{Method}

The study was approved by the Medicine Health Research Ethical Clearance Commission (016/HRECC. FODM/III/2018). Each respondent who participated in the study had consented to voluntary informed consent. Respondents in this study were educated working mothers aged $21-40$ years.

Research Design: This cross-sectional study was conducted on 101 working mothers in Banjarbaru. Sampling was done by cluster random sampling. Sample criteria were mothers who worked and had preschool children aged 5-6 years. Data was obtained using questionnaires. Instrument behavior consisted of 6 statements that contained the behavior of mothers in the dental health of preschool children aged 5-6 years. Each answer was given with a score of 0-1.

Statistical Analysis: Data were analyzed using SPSS 16 for Windows. Nonparametric Descriptive Statistics used logistic regression with the level of significance value was $<0.05$.

\section{Results}

There were two independent variables, age and education, and one dependent variable, the behavior of the dental health of the mother. All variables can be seen in Table 1. There were 33 (32.7\%) working mothers aged $21-30,68$ persons with age $31-40,22$ persons $(21.8 \%)$ with low education, and 79 persons $(78.2 \%)$ with high education. Analysis using SPSS version 16 Software for Windows showed that there was no significant relationship between educated working mothers' age on dental health behaviors of a preschooler. The results can be seen in Table 2 .

Table 1: Distribution of age and education of working mothers in Banjarbaru

\begin{tabular}{|c|c|c|c|}
\hline Variables & Category & Total & Percentage \\
\hline \multirow{2}{*}{$\begin{array}{c}\text { Age of } \\
\text { caregiver }\end{array}$} & $21-30$ years & 33 & 32.7 \\
\cline { 2 - 4 } & $31-40$ years & 68 & 67.3 \\
\hline $\begin{array}{c}\text { Education of } \\
\text { caregiver }\end{array}$ & Low & 22 & 21.8 \\
\cline { 2 - 4 } Total & High & 79 & 78.2 \\
\hline & 101 & 100 \\
\hline
\end{tabular}

Table 2: Cross-tabulation of the relationship between age and education of working mothers on dental health behavior in preschool children aged 5-6 years in Banjarbaru

\begin{tabular}{|c|c|c|c|c|c|c|c|c|c|}
\hline \multirow{2}{*}{\multicolumn{2}{|c|}{ Mother behavior }} & \multicolumn{2}{|c|}{ Age } & & & \multicolumn{2}{|c|}{ Education } & \multirow{2}{*}{ OR } & \multirow{2}{*}{ Sig. } \\
\hline & & $\begin{array}{c}21-30 \\
\%\end{array}$ & $\begin{array}{c}31-40 \\
\% \\
\end{array}$ & OR & Sig. & Low & High & & \\
\hline \multirow{2}{*}{$\begin{array}{l}\text { Telling children to clean their teeth } \\
\text { after meal }\end{array}$} & Bad & 788 & 770 & \multirow[b]{2}{*}{0.963} & \multirow{2}{*}{0.945} & 818 & 772 & \multirow[b]{2}{*}{1.348} & \multirow[b]{2}{*}{0.647} \\
\hline & Good & 212 & 221 & & & 182 & 228 & & \\
\hline \multirow{2}{*}{$\begin{array}{l}\text { Having their children clean their } \\
\text { teeth before going to bed at night }\end{array}$} & $\mathrm{Bad}$ & 60.6 & 51.5 & \multirow{2}{*}{1.297} & \multirow{2}{*}{0.574} & 63.6 & 51.9 & \multirow{2}{*}{1.647} & \multirow{2}{*}{0.468} \\
\hline & Good & 39.4 & 48.5 & & & 36.4 & 48.1 & & \\
\hline
\end{tabular}


Conted...

\begin{tabular}{|c|c|c|c|c|c|c|c|c|c|}
\hline \multirow{2}{*}{$\begin{array}{l}\text { Cleaning teeth every morning after } \\
\text { breakfast and night before bed }\end{array}$} & $\mathrm{Bad}$ & 48.5 & 39.7 & \multirow{2}{*}{1.313} & \multirow{2}{*}{0.550} & 50 & 40.5 & \multirow{2}{*}{1.320} & \multirow{2}{*}{0.591} \\
\hline & Good & 51.5 & 60.3 & & & 50 & 59.5 & & \\
\hline \multirow{2}{*}{$\begin{array}{l}\text { Allowing children to eat snacks } \\
\text { every day }\end{array}$} & $\mathrm{Bad}$ & 36.4 & 42.4 & \multirow{2}{*}{0.802} & \multirow{2}{*}{0.635} & 36.4 & 41.8 & \multirow{2}{*}{0.869} & \multirow{2}{*}{0.791} \\
\hline & Good & 63.6 & 57.4 & & & 63.6 & 58.2 & & \\
\hline \multirow{2}{*}{$\begin{array}{l}\text { Telling children to use toothbrushes } \\
\text { and toothpaste every day }\end{array}$} & $\mathrm{Bad}$ & 9.1 & 17.6 & \multirow{2}{*}{0.75} & \multirow{2}{*}{0.684} & 0 & 19 & \multirow{2}{*}{0.000} & \multirow{2}{*}{0.998} \\
\hline & Good & 90.9 & 82.4 & & & 100 & 81 & & \\
\hline \multirow{2}{*}{$\begin{array}{l}\text { Having their children rinse after } \\
\text { eating }\end{array}$} & $\mathrm{Bad}$ & 78.8 & 60.3 & 2.678 & 0.063 & 68.2 & 65.8 & \multirow{2}{*}{0.758} & \multirow{2}{*}{0.625} \\
\hline & Good & 21.2 & 39.7 & & & 31.8 & 34.3 & & \\
\hline
\end{tabular}

Mother's behavior in telling children to clean teeth after every meal had no significant relationship with age $(\mathrm{p}=0,945, \mathrm{OR}=0.963)$ and education $(\mathrm{p}=0,647, \mathrm{OR}=$ $1,348)$. At the age of 21-30 years old, mother's behavior on dental health was mostly bad as much as $78.8 \%$ with low level of education equal to $81.8 \%$, whereas at age 31-40 years old, mother's behavior on dental health was mostly bad as much as $77.9 \%$ with high education level of $77.2 \%$. Mother's behavior in telling children to clean teeth before bedtime had no significant relationship with age $(\mathrm{p}=0.574, \mathrm{OR}=1.294)$ and education $(=0.468$, OR $=1.467)$. At the age of 21-30 years old mother's behavior toward dental health was mostly bad as much $60,6 \%$ with low education level equal to $63.6 \%$, whereas at age 31-40 years old, mother's behavior to the dental health of child was mostly bad as much $51,5 \%$ with the higher education level of $51.9 \%$. The behavior of mothers to clean the teeth every morning after breakfast and the night before bed had no significant relationship with age $(\mathrm{p}=0.55, \mathrm{OR}=1.313)$ and education $(\mathrm{p}=0.591, \mathrm{OR}=$ 1.32). At the age of 21-30 years old, mother's behavior toward dental health of children was mostly good as much as $51.5 \%$ with low education level of $50 \%$, whereas, at age 31-40 year, majority of mother behavior to dental health of child was mostly good as much as $60.3 \%$ with education level high of $59.5 \%$. The behavior of mothers who let children eat a snack every day had no significant relationship with age $(\mathrm{p}=0.635, \mathrm{OR}=0.802)$ and education $(p=0.869, \mathrm{OR}=0.998)$. At the age of 21-30 years old, mother's behavior toward dental health of children was mostly good as much as $63.6 \%$ with low education level equal to $63.6 \%$, whereas at age $31-40$ years old, mother's behavior to dental health of child was mostly good as much as $57,4 \%$ with high education level of $58.2 \%$. Mother's behavior in telling children to use toothbrush and toothpaste every day had no significant relationship with age $(p=0.684, \mathrm{OR}=0.75)$ and education $(p=0.999, O R=0.000)$. At the age of 21 -
30 years old, mother's behavior toward dental health of children was mostly good as much as $90.9 \%$, although they had low education, Whereas, at age 31-40 years old, mother's behavior to dental health of children was mostly good as much as $81 \%$ with high education level equal to $58.2 \%$. The mother's behavior of having a mouthwash after eating had no significant relationship with age ( $p$ $=0.063, \mathrm{OR}=2.676)$ and Education $(\mathrm{p}=0.625, \mathrm{OR}=$ 0.758 ). At the age of 21-30 years old, mother's behavior toward dental health was mostly bad as much as $78.8 \%$ with a low level of education equal to $68.2 \%$. Whereas, at age 31-40 years old, mother's behavior to the dental health of children was mostly good as much as $60.3 \%$ with the high education level of $65.8 \%$.

\section{Discussion}

According to the literature, behavior building is affected by attitude and knowledge, which can be gained from both formal and non-formal education ${ }^{13}$. Previous studies stated that education level reflect knowledge and skills to make health behavior choices ${ }^{14,15}$. The mothers' dental health behavior is an important factor in building the children's dental health behavior ${ }^{6,14}$ socioeconomic status, oral health behaviors of children and their parents. Oral health status of children was examined. The parent and their children oral health relationship were tested using regression and correlation analysis. Results. About 222 parents and children participated in the study. There was a significant relationship between history of having dental problems in parents and $\mathrm{dmft}$ index in their children $(\mathrm{P}=0.01$. Education may have various impact on individual, depend on personality, social environment, culture, and perception. Besides, education also increase the career opportunity. The working environment in public sector has high pressure that may induce stress, and affecting a person behavior, hence, behavior is more influenced by personality of a person than the level of 
education ${ }^{16,17}$. The result is in accordance with previous research which showed that the level of education does not affect the working mother's behavior toward the dental health of preschool children aged 5-6 years. Education is a program to develop personality and abilities that last a lifetime. The higher education, the easier the person to receive information. The more information that comes in, the more the knowledge gained. Knowledge is very close to education, so it is expected that someone with higher education will have better knowledge, including health care ${ }^{12,18}$.

Table 2 showed that the mother's behavior toward child's dental hygiene is not correlated to education. Lack of knowledge and access to information, causing a person to have limited knowledge about the hazard of unhealthy behavior so less motivation to adopt healthy behavior $^{16}$. Learning process may enhance professional skills and specific knowledge that are still relevant to general knowledge ${ }^{19}$. Education plays an important role in caries prevention. Parents with higher education had more concern to the oral health of children, that make them have a better oral health behavior ${ }^{20,21}$. Behavior is the biggest factor affecting one's health. Developmental psychology states that the age of 18-40 years is an early adulthood. As getting older, the maturity and strength of a person will be more mature in thinking and work $^{22}$. Danang and Irdawati stated that age is one of the factors that influence mothers to be able to run the role of optimal care. The age of the mother or the parent who has reached maturity in thinking and being able to properly educate and nurture the child will be able to reach the stage of development according to his time ${ }^{23,24}$.

Working mother's behavior towards spending more time at work than at home. This causes the mother to have little time with the children so that the oral hygiene practice of children is sometimes neglected because of the activities. Based on the data obtained, it was shown that the mother who worked in the city of Banjarbaru, South Kalimantan aged 21-40 years old had high education. Supposedly, with age, a person has better knowledge about dental and mouth health, so that the practice of oral hygiene is also good. However, in this study different things were obtained that the age and level of education had no relationship with the behavior of working mothers on the dental health behavior of preschool children aged 5-6 years in Banjarbaru, South Kalimantan. Working mothers have high stress because of their work ${ }^{16,17}$. Exhaustion after work tends to make mothers do not care about the dental and oral health of children. This is in accordance with the results of a study that states that good knowledge was not always directly proportional to the pattern of parenting ${ }^{6,24}$ ${ }^{26}$ socioeconomic status, oral health behaviors of children and their parents. Oral health status of children was examined. The parent and their children oral health relationship were tested using regression and correlation analysis. Results. About 222 parents and children participated in the study. There was a significant relationship between history of having dental problems in parents and $\mathrm{dmft}$ index in their children $(\mathrm{P}=0.01$, meaning that although the mother has a good knowledge about oral health, it does not necessarily make her have a good attitude to apply the knowledge.

\section{Conclusion}

Age and education of working mothers do not affect dental health behaviors in preschool children aged 5-6 years in healthcare prevention and maintenance efforts. However, the personality of the caregiver affects this behavior. Caregivers who work tend to have a high level of stress so that after coming home from work, the behavior that appears is the behavior as it is, meaning not so concerned about the dental health of children.

Conflict of Interests: None declared

Source of Funding: This research is self-funded.

\section{REFERENCES}

1. Cheng C, Huang K, Chen C, IJ Y. Correlation Between Dental Caries and Diet, Oral Hygiene Habits, and Other Indicator among Elementary School Students in Xiulin Township, Hualien County, Taiwan. Tzu Chu Med J. 2011;26:176-81.

2. Wigen I, Wang N. Parental Influence on Dental Caries Development in Preschool Children an Overview with Emphasis on Recent Norwegia Research. Nor Epidemiol. 2012;22:13-9.

3. Kemenkes RI. Riset Kesehatan Dasar 2013. Minist Heal Repub Indones. 2013;(1):1-303.

4. Nurwati B. Hubungan Karies Gigi Dengan Kualitas Hidup Pada Anak Sekolah Usia 5-7 Tahun Di Kecamatan Landasan Ulin Kota Banjarbaru Kalimantan Selatan. 2015. 
5. Shetty D, Rat S, Tamkar. Influence of mother oral health care knowledge on the oral health status of their child. Saudi J Oral Sci. 2016;3(1):12-5.

6. Bozorgmehr E, Hajizamani A, Malek Mohammadi T. Oral health behavior of parents as a predictor of oral health status of their children. ISRN Dent [Internet]. 2013;2013:741783. Available from: http:/www.pubmedcentral.nih.gov/articlerender. fcgi artid $=3664493 \&$ tool $=$ pmcentrez \& rendertype $=$ abstract

7. Talekar RG, Slade D, Ennet. Parental Perception of Their Preschool-aged children's Oral Health. J Am Dent Assoc. 2005;136:364-72.

8. MLEE R, T M, Sumarlan. Wanita Dalam Dunia Kerja. Bandung: Alfabeta; 2012.

9. Ardilla F, Ellyn N, Hastuti P. Motivasi Wanita Pekerja di Industri Kecil dan Rumah Tangga (IKRT) Kain Sasirangan Kelurahan Seberang Mesjid Kecamatan Banjarmasin Tengah Kota Banjarmasin. J Pendidik Geogr. 2015;2(5):1-14.

10. Julaiha. Pengaruh Status Sosial Ekonomi Keluarga Terhadap Minat Melanjukan Ke Perguruan Tinggi. 2015.

11. Program Studi Bimbingan Konseling FKIP Universitas Islam Kalimantan Muhammad Arsyad Al Banjary Banjarmasin. J Mhs Bk AnNur. 1(1):45-51.

12. Zhu D. Understanding Middle-Class Consumers from The Justification of Taste a Case Study of Beijing. J Chinese Sociol. 2016;3:4.

13. Budiharato. Pengantar Ilmu Perilaku Kesehatan Dan Pendidikan Kesehatan Gigi. Jakarta: EGC; $2013.6 \mathrm{p}$.

14. Notoadmodjo. Promosi Kesehatan dan Ilmu Perilaku. Jakarta: Rinneka Cipta; 2005. 77-82 p.

15. Holley M S, Boganin S, Kilpatrick. Parental influence and development of Dental caries in Children Age Years: a Systematic Review of literature. J Dent. 2012;40:873-85.

16. Manna A, Carlen A, Lingstrom. Dental caries and Associated Faktor in Mother and Their Preschool and School Children A Cross-Sectional study. J Dent Sci. 2013;8:101-8.

17. Pampel F, Krueger P, Denney J. Socioeconomic disparities in health behaviors. Annu Rev Sociol. 2010;36:349-70.

18. Kawachi I, Subramanian S. Neighborhood influences on health. J Epidemiol Community Health. 2007;61(1):3-4.

19. Budiman, Riyanto A. Pengetahuan dan Sikap dalam penelitian Kesehatan. Kapita Selekta Kuesioner. Jakarta: Salemba Medica; 2013.

20. Pradono J, Sulistyowati N. Correlation between Education Level, Knowledge of Environmental Health, Healthy Behavior with Health Status Correlation Studi on People Aged 10-24 in Jakarta Pusat. Bull Penelit Kesehat. 2013;1:89-95.

21. Tamimi A, Pani C. Dietary and Geographic and Culture Factor as a Predictor of Dental Caries risk among Children in Saudi Arabia-A Systematic Review. Prim Heal Care. 2015;5(2):1000195.

22. Jain R, Oswal C, Chiguppi R. Knowledge, Attitude, and Practice of Mother toward Their Children's Oral Health: A questioner survey among subpopulation in Mumbai (India). J Dent Res Sci Dev. 2014;1(2):40-5.

23. Hurlock E. Psikologi Perkembangan. 5th ed. Jakarta: Erlangga; 2002.

24. Danan S, Irdawati. Hubungan antara Pola Asuh Orang Tua dengan Kemandirian Anak Usia PraSekolah di Tk Aisyiyah Mendungan Sukoharjo. J Komun Kesehat. 2012;3(1):1-7.

25. Amin M, Nyachhyon P, Elyasi M, Nuami M. Impact of an Oral Health Education Workshop on Parents Oral Health Knowledge, Attitude and Perceived Behavioral Control Among African Immigrants. J Oral Dis. 2014;

26. Sanders M, Morawska A. Can Changing Parental Knowledge, Dysfunctional Expectations, and Attribution, and Emotion Regulation Improve outcomes for Children. Parenting Skill. 2014. 